\title{
USE OF CARBON CATALYSTS FOR OXIDATIVE DESTRUCTION OF WASTEWATERS
}

\author{
Svetlana S. Stavitskaya, Nikolai T. Kartel* \\ Institute for Sorption and Problems of Endoecology, NAS of Ukraine, \\ 13, General Naumov street, 03164, Kyiv, Ukraine \\ Corresponding author: Tel/Fax+380 44 4529325; E-mail: nikar@kartel.kiev.ua
}

\begin{abstract}
The paper considers a possibility of using the catalytic action of the carbonaceous adsorbents modified by different ways for the purification of various solutions, natural and wastewaters. It has been found that the oxidative destruction of organic (phenols, dyes, pesticides, etc.) and inorganic $\left(\mathrm{H}_{2} \mathrm{~S}\right)$ contaminants in water solutions is considerably intensified in the presence of both ordinary activated carbons and especially, carbons with specially introduced catalytic additives. It is shown that the sewage treatment level is strongly affected by the amount and nature of a modifying agent introduced on the carbon surface.
\end{abstract}

Keywords: carbon, catalysis, oxidation, destruction, wastewaters.

\section{INTRODUCTION}

For effective removal of a number of organic contaminants from wastewaters it is often necessary to destroy them and to this end wastewaters are treatment with oxidizers [1-3]. Chlorination and ozonation are the most popular oxidative destruction methods. Ozone treatment at that is more preferable, owing to the ecologically cleaner method. The same advantage, i.e., the absence of the reduction by-products, is available when using molecular oxygen and hydrogen peroxide as oxidizers, however, the application of the latter two is rather limited, since in usual conditions they posses low reaction capability and are activated only in the presence of catalysts. Ions of metals having variable valence, for instance, can be used as catalysts. Data of paper [4] describe a positive experience in using oxygen in the presence of microquantities of iron, nickel, and chromium for wastewater purification from sulfur-containing compounds, oil products, and phenols. Hydrogen peroxide in the presence of $\mathrm{Fe}^{2+}$ and $\mathrm{Fe}^{3+}$ oxidizes $30-65 \%$ of organic contaminants from domestic sewage and in this case almost completely (by 98\%) to $\mathrm{CO}_{2}$ and also waters that do not contain phenols, organic solvents, etc. $[2,4]$.

Some papers $[3,5]$ indicate the expediency of using the oxidation-sorption method of purification from organic impurities, in which an oxidizer (ozone, chlorine, potassium permanganate) is introduced to the contaminated water and the water is filtered through a layer of activated carbon (AC). With such a method the increases in the purification level is usually much higher than during the summation of oxidation and sorption. As the authors of ref. [3] believe the improvement of the indices is attained, on the one hand, at the expense of greater sorption of the destruction products and, on the other hand, at the expense of more effective oxidation on surface, owing to the increase of the concentration of reacting substances on it. Although, ref. [3] contains a direct indication on the catalytic action of carbons, however, the phenomena described, most likely, are determined by catalytic actions of carbons, which, as well known, effectively accelerate many processes of oxidizing organic and inorganic substances by molecular oxygen and hydrogen peroxide both in the liquid and in gas phases [8-13]. However, the catalytic action of carbons, when considering the processes of the carbon-sorption purification of sewage from organic contaminants, in the majority of cases is not taken into account, although as it can be assumed the establishment of the catalytic phenomena and their controlled use can help in intensification of sewage treatment processes.

The present paper considers some possibilities of using the catalytic actions of various carbonaceous active materials modified by different methods for the sewage treatment.

\section{RESULTS AND DISCUSSION}

From the data of our previous papers [6,8-12] it follows that the catalytic actions of carbon materials to some degree could be controlled by changing the nature of their surfaces, by the introduction in their structure and in the surface of certain functional groups and compounds, ions, and complexes of metals. Proceeding from it, to perform the analysis of the oxidative destruction processes when removing impurities from waters solutions we used carbons with different chemical compositions of the surface (ordinary, oxidized, and nitrogen-containing), containing different surface functional groups and having catalytic active ions of metals (Fe(II), Fe (III), Ni (II), Co (II), Cr (III), etc.) bound into surface complexes or immobilized complexes of metals and other catalytic additives (CA). The main physical-chemical 
characteristics of the used carbons are given in Tab. 1. It shows the data on porosity and ion exchange properties of carbons, on whose basis we prepared catalysts. As a rule, when preparing, for instance, the ion-substitution forms or during the impregnation by the catalytically active substances, the volume of sorption pores and, respectively, the volumes of micro- and mesopores some decrease. However, such decreasing is small, when using 1-2\% of the pores filling and does not change the porosity nature substantially [11].

Table 1

Physical-Chemical Characteristics of Carbons

\begin{tabular}{|c|c|c|c|c|c|c|}
\hline \multirow[t]{2}{*}{ Catalyst sample } & \multirow{2}{*}{$\begin{array}{c}\text { Volume of } \\
\text { sorption pores, } \\
\left(\mathrm{W}_{\mathrm{s}}\right), \mathrm{cm}^{3} / \mathrm{g}\end{array}$} & \multirow[t]{2}{*}{$\begin{array}{l}V_{\text {meso' }} \\
\mathrm{cm}^{3} / \mathrm{g}\end{array}$} & \multirow[t]{2}{*}{$\begin{array}{l}V_{\text {micron }}, \\
\mathrm{cm}^{3} / \mathrm{g}\end{array}$} & \multirow{2}{*}{$\begin{array}{c}\text { Specific } \\
\text { surface area } \\
\left(\mathrm{S}_{\mathrm{sp}}\right), \mathrm{m}^{2} / \mathrm{g}\end{array}$} & \multicolumn{2}{|c|}{$\begin{array}{c}\text { Static exchange capacity, } \\
\mathrm{mM} / \mathrm{g}\end{array}$} \\
\hline & & & & & HCI & $\mathrm{NaOH}$ \\
\hline AU-1 & 0.52 & 0.21 & 0.31 & 423 & 0.45 & 0.16 \\
\hline AU-2 & 0.48 & 0.28 & 0.30 & - & 0.46 & 0.14 \\
\hline AU-3 & 0.55 & 0.25 & 0.30 & 380 & 0.8 & 0.11 \\
\hline AU-4 & 0.65 & 0.20 & 0.45 & 520 & 0.20 & 2.50 \\
\hline AU-5 & 0.55 & 0.20 & 0.35 & 450 & 0.15 & 2.80 \\
\hline AU-6 & 0.35 & 0.15 & 0.20 & - & 0.10 & 2.70 \\
\hline AU-7 & 0.70 & 0.21 & 0.47 & 850 & 0.10 & 2.70 \\
\hline AU-8 & 0.90 & - & - & - & 0.20 & 1.00 \\
\hline AU-9 & 0.27 & 0.10 & 0.17 & 350 & 0.10 & 2.50 \\
\hline AR-3 & 0.45 & 0.15 & 0.30 & 418 & 0.45 & 0.21 \\
\hline $\mathrm{SCN}$ & 0.68 & 0.28 & 0.40 & 630 & 0.67 & 0.12 \\
\hline
\end{tabular}

The experiments were conducted using both model solutions of the known composition containing phenols, dyes, organic acids, pesticides, sulfides, and real, in particular industrial sewage with a set of different separately no identifiable organic contaminants.

Hydrogen peroxide and molecular oxygen were used mainly as oxidizers; in some cases (for comparison) we used oxidation by sodium hypochlorite and ozone.

We investigated the processes involving the removal of phenol, methylene blue, congo red, mixtures of pesticides, mixtures of organic acids after contact with oxidizers and individual activated carbons, both initial and modified (Tables 2 and 3, Fig. 1). For comparison, we also used homogeneous activators of hydrogen peroxide - the mixture of ions of two-or three-valence iron.

As could be expected, given the treatment with oxidizers the concentrations of organic substances some decreased. When in contact with AC as a result of adsorption we could observe a distinct removal of the mentioned substances. However, if in identical concentrations and temperature conditions and the same contact time we try to perform the simultaneous action of an oxidizer and adsorbent, the purification level is much higher (Tab. 2 and Fig.1).

Table 2

Removal of Organics from Model Solutions

\begin{tabular}{|c|c|c|c|c|}
\hline Substance & Oxidizer & Carbon material & Catalyst & $\begin{array}{c}\text { Purification level, } \\
\%\end{array}$ \\
\hline \multirow{4}{*}{ Phenol } & - & AR-V & - & 25 \\
\hline & \multirow{3}{*}{$\mathrm{H}_{2} \mathrm{O}_{2}$} & - & - & 15 \\
\hline & & - & $\mathrm{Fe}(\mathrm{II})+\mathrm{Fe}(\mathrm{III})$ & 43 \\
\hline & & AR-V & AR-V (CA) Fe (II) + Fe (III) & 88 \\
\hline \multirow{4}{*}{ Congo red } & - & AR-V & - & 28 \\
\hline & \multirow{3}{*}{$\mathrm{H}_{2} \mathrm{O}_{2}$} & - & - & 10 \\
\hline & & - & $\mathrm{Fe}(\mathrm{II})+\mathrm{Fe}(\mathrm{III})$ & 31 \\
\hline & & AR-V & AR-V (CA) Fe (II) + Fe (III) & 73 \\
\hline \multirow{4}{*}{ Mixture of pesticides } & - & AU-1 & - & 22 \\
\hline & \multirow{3}{*}{$\mathrm{H}_{2} \mathrm{O}_{2}$} & - & - & 10 \\
\hline & & - & $\mathrm{Fe}(\mathrm{II})+\mathrm{Fe}(\mathrm{III})$ & 31 \\
\hline & & AU-1 & AR-V (CA) Fe (II) + Fe (III) & 68 \\
\hline \multirow{4}{*}{$\begin{array}{l}\text { Mixture of organic } \\
\text { acids }\end{array}$} & - & AU-1 & - & 38 \\
\hline & \multirow[t]{3}{*}{$\mathrm{H}_{2} \mathrm{O}_{2}$} & - & - & 8 \\
\hline & & - & $\mathrm{Fe}(\mathrm{II})+\mathrm{Fe}(\mathrm{III})$ & 18 \\
\hline & & AU-1 & AU-1 (CA) Fe (II) + Fe (III) & 55 \\
\hline
\end{tabular}


It is most likely, that it is achieved at the expense of the catalytic action of AC. This is also indicated by the fact that a similar, although much smaller increase in the purification level, is observed also in the presence of homogeneous activators, in particular, hydrogen peroxide - the mixture of Fe (III) - Fe (III) ions. However, ions adsorbed by carbons, as it follows from [12], should be more catalytically active. We could also observe a certain dependence of the purification level from the nature of carbons and type of modifying additives.

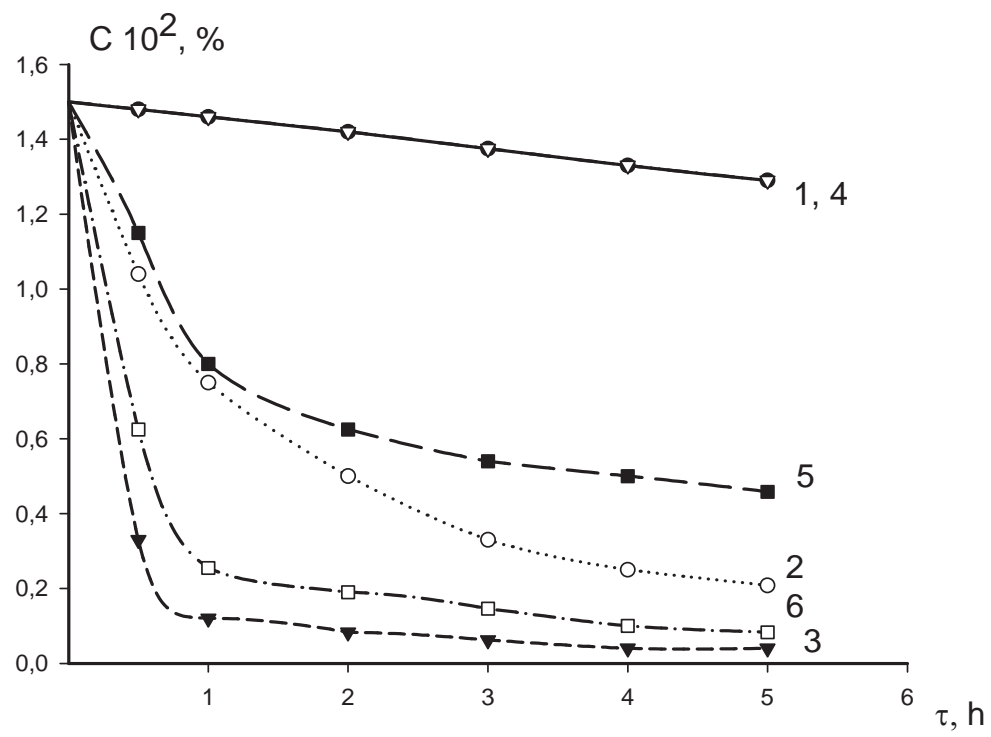

Fig. 1. Dependence of the content of methylene blue $(1,2,3)$ and phenol $(4,5,6)$ in the solution from contacting time with hydrogen peroxide $(1,4)$, carbon $\mathrm{SCN}(2,5)$, and $\mathrm{SCN}+\mathrm{H}_{2} \mathrm{O}_{2}$ system $(3,6)$.

Indeed, earlier [8,9] it was shown that the catalytic oxidation by oxygen, for instance, of carbons is substantially affected by the nature of carbon and modifiers - ions of metals. The same factors also produce great influence on the oxidation of dibenzyl ester [6] and other similar processes.

As for the removal of organic substances from water solutions in the system "substance $\mathrm{R}+$ oxidizer $\left(\mathrm{O}_{\mathrm{x}}\right)+$ $A C$ ", in particular, for cation substitution forms, the oxidative destruction may be following:

$$
\begin{aligned}
& \left(\mathrm{H}_{2} \mathrm{O}_{2}\right) \\
& \mathrm{AC} \mathrm{Me}^{\mathrm{z}^{+}}+\mathrm{R}+\mathrm{O}_{\mathrm{x}}\left(\mathrm{H}_{2} \mathrm{O}_{2}, \mathrm{O}_{2} \ldots\right) \rightarrow \mathrm{AC} \mathrm{Me}^{\mathrm{z+}}\left(\mathrm{HO}_{2}{ }^{*}\right)+\mathrm{H}_{2} \mathrm{O}+\text { Oxidation products or } \mathrm{CO}_{2} \text {, } \\
& \left(\mathrm{R}^{*}\right)(\mathrm{R})
\end{aligned}
$$

where the substance $(\mathrm{R})$ being adsorbed and the oxidizer $\left(\mathrm{O}_{\mathrm{x}}\right)$, for instance, $\mathrm{H}_{2} \mathrm{O}_{2}$, the radical $\mathrm{HO}_{2} *$ or other radicals may hold the vacancies of the coordination sphere of the metal ion adsorbed in the surface complex. In this case we can ensure a tighter contact of reacting substances, which leads to the acceleration of the process. Such pattern of the process has been described in [13] for the catalytic regeneration of carbons.

Oxidative destruction in the processes investigated may take place both parallel to the formation of low-molecular products including carbon dioxide and water. The emergence of the destruction products is registered by the methods of IR- and UV-spectroscopy, while the excess amount of $\mathrm{CO}_{2}$ in vessels, where the experiments were performed, by gas chromatography. The spectral and gas-chromatographic data were aimed, largely, to provide a qualitative confirmation of the described pattern of catalytic destruction. The qualitative determination of the destruction products and drawing a material balance in this case is difficult, due to the process complexity of the particular sorption of the destruction products.

The data obtained provided a basis to assume that the combination of sorption with catalytic oxidative destruction on modified AC with catalytic additives makes it possible to substantially intensify the process of sewage treatment. Respective experiments were performed with real sewage from several plants, which contained a sum of different organic impurities. The levels of contamination and treatment were determined by the COD (mg O/L) changes. In some cases we also determined the $\mathrm{CO}_{2}$ amount in a closed space of the reaction vessels.

The experiments have shown that the combination of sorption on AC with catalytic destruction of impurities, in fact, much greater improves the process of purification (Tab. 3) in comparison with the effects of only oxidizers or only sorption purification. Destruction with such combined method occurs mainly till carbon dioxide and water. If the respective experiments are performed in dynamic conditions, as this is in the case of a lot of technological processes, 
the volume of the solution purified till the breakthrough of the impurities to the filtrate increases essentially and the time of protective action become longer (Fig. 2). This makes it possible to refer this process as "catalytically prolonged sorption".

Table 3

Removal of Organics from Wastewaters

\begin{tabular}{|c|c|c|c|c|}
\hline Mixture of organics & Oxidizer & $\begin{array}{c}\text { Carbon } \\
\text { material }\end{array}$ & Catalyst & $\begin{array}{c}\text { Purification } \\
\text { level, \% }\end{array}$ \\
\hline \multirow{10}{*}{$\mathrm{COD}=3490 \mathrm{mg} \mathrm{O} / \mathrm{L}$} & - & AU-2 & - & 35 \\
\hline & $\mathrm{H}_{2} \mathrm{O}_{2}$ & - & - & 10 \\
\hline & $\mathrm{O}_{2}$ & - & - & 5 \\
\hline & $\mathrm{H}_{2} \mathrm{O}_{2}$ & - & $\mathrm{Fe}(\mathrm{II})+\mathrm{Fe}(\mathrm{III})$ & 19 \\
\hline & & \multirow{4}{*}{ AU-2 } & - & 32 \\
\hline & & & AU-2 (CA) & 58 \\
\hline & & & $(\mathrm{Fe}(\mathrm{II})+\mathrm{Fe}(\mathrm{III})) \mathrm{AU}-2(\mathrm{CA})$ & 89 \\
\hline & $\mathrm{O}_{2}$ & & $(\mathrm{Fe}(\mathrm{II})+\mathrm{Fe}(\mathrm{III})) \mathrm{AU}-2(\mathrm{CA})$ & 68 \\
\hline & $\mathrm{H}_{2} \mathrm{O}_{2}$ & \multirow[t]{2}{*}{ AU-3 } & AU-3 (CA) (Fe) & 92 \\
\hline & $\mathrm{O}_{2}$ & & AU-3 (CA) & 85 \\
\hline \multirow{8}{*}{$\mathrm{COD}=2590 \mathrm{mg} \mathrm{O} / \mathrm{L}$} & - & \multirow[t]{2}{*}{ AU-2 } & - & 33 \\
\hline & $\mathrm{H}_{2} \mathrm{O}_{2}$ & & AU-2 (CA) & 78 \\
\hline & \multirow[t]{2}{*}{$\mathrm{O}_{2}$} & - & - & 5 \\
\hline & & AU-2 & AU-2 (CA) & 63 \\
\hline & \multirow{2}{*}{$\begin{array}{c}\mathrm{O}_{3} \text { (ozone-air } \\
\text { mixture) }\end{array}$} & - & - & 22 \\
\hline & & - & - & 18 \\
\hline & $\mathrm{NaClO}$ & AU-2 & AU-2(CA) & 52 \\
\hline & $\mathrm{NaClO}$ & AU-3 & - & 78 \\
\hline $\mathrm{COD}=78 \mathrm{mg} \mathrm{O} / \mathrm{L}$ & - & AU-3 & AR-3 (CA) & 95 \\
\hline
\end{tabular}

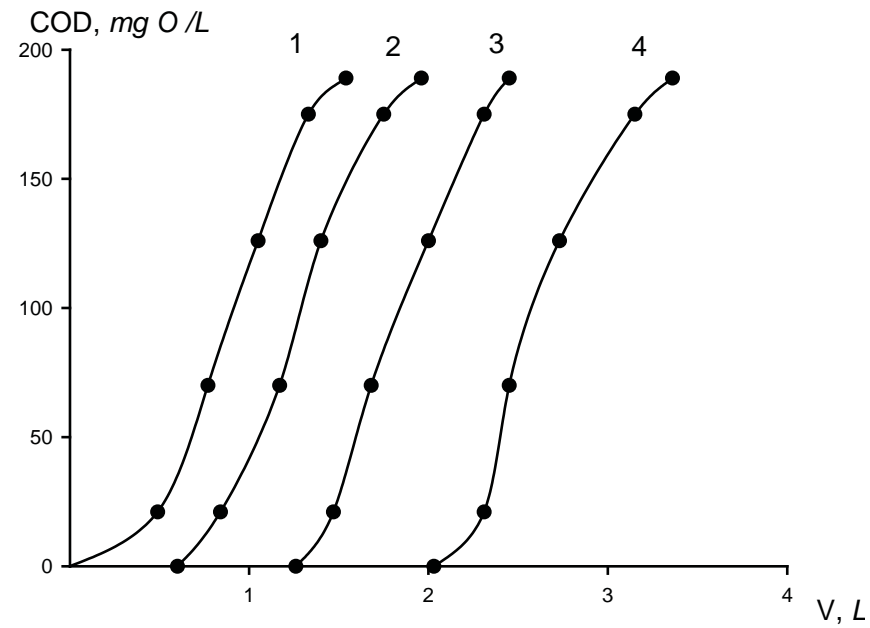

Fig. 2. Output curves of sorption of the mixture of organics from sewage on carbons AU-1 $(1,2)$ and AU-4 $(3,4)$ in the absence $(1,3)$ and in the presence $(2,4)$ of hydrogen peroxide and catalytic additives.

Activated carbons including those modified by cations of metals accelerate oxidation not only of organic but also inorganic substances including sulfuric compounds in the reduced from. These compounds, in particular, hydrogen sulfide are contaminants of natural and wastewaters encountered very often which necessitates their purification before use.

One of the ways to solve this problem is oxidation of sulfate forms by oxygen of air in the presence of catalysts. References [14] show that in addition to inorganic catalysts - caolinite, clinoptilolite etc. - the acceleration of hydrogen sulfide oxidation by oxygen of air may take place in the presence of carbon materials.

We have verified the use of carbon catalysts for the purification from hydrogen sulfide to the MPC level of the solutions modeling natural and wastewaters contaminated with these components. The content of natural sulfur was 
within the range of $300 \mathrm{mg} / \mathrm{L}$. The experiments were performed in alkaline and neutral media. As follows from Tab. 4 , the purification of the solutions is taking place in the presence of activated carbons. The activity of carbon catalysts can be regulated by the change of the chemical nature of the surfaces of catalysts, by the introduction the surface complexes of these or other cations. For a given process nickel forms oxidized carbons appeared the most active.

Table 4

Purification of Water from Hydrogen Sulfide during Oxidation by Oxygen in the Presence of Carbon Catalysts

\begin{tabular}{|c|c|c|}
\hline Catalyst & SCA*, mol $\mathbf{O}_{\mathbf{2}}$ / (g・min) & $\begin{array}{c}\text { Purification level, } \\
\text { rel. units** }\end{array}$ \\
\hline Without catalyst & $4.0 .10^{-6}$ & 1 \\
\hline AU-4-initial & $8.0 .10^{-5}$ & 20 \\
\hline AU-4 (CA) & $4.0 .10^{-4}$ & 1000 \\
\hline AU-5 (CA-1) & $1.0 .10^{-4}$ & 250 \\
\hline AU-5 (CA-2) & $5.7 .10^{-4}$ & 1430 \\
\hline AU-5 (CA-3) & $8.8 .10^{-4}$ & 2200 \\
\hline Without catalyst & $1.0 .10^{-6}$ & 50 \\
\hline AU-6 (CA-Cr) & $3.0 .10^{-5}$ & 100 \\
\hline AU-6 (CA-Co) & $1.0 .10^{-4}$ & 170 \\
\hline AU-6 (CA-Mn) & $1.7 .10^{-4}$ & 820 \\
\hline AU-6 (CA-Fe) & $8.2 .10^{-4}$ & 1600 \\
\hline AU-6 (CA-Cu) & $1.6 .10^{-3}$ & 3400 \\
\hline AU-6 (CA-Ni) & $3.4 .10^{-3}$ & \\
\hline
\end{tabular}

*SCA - specific catalytic activity; ** Level hydrogen sulfide removal was calculated in respect to the treatment of the same volume of water without catalyst.

\section{CONCLUSIONS}

The investigations conducted showed that the use of carbon catalysts in the oxidative destruction methods of wastewater treatment is promising both from organic and inorganic contaminants. On the basis of the obtained data it is possible to ascertain that the combination of adsorption with catalytic oxidative destruction on active carbons modified by catalytic additives allows essentially intensify a process of clearing wastewaters.

\section{REFERENCES}

[1] Сычев, Ф.Я.; Травин, С.О.; Дука, Г.Г.; Скурлатов, Ю.И., Каталитические реакции и охрана окружающей среды, Штиинца: Кишинев, 1983, 271.

[2] Селюков, А.В.; Травин, А.И., В кн.: Производство и потребление перекиси водорода. Труды Всесоюзной конференции, Ленинград, 1987, 46-50.

[3] Луценко, Г.Н.; Цветкова, А.И.; Свердлов, И.Ш., Физико-химическая очистка городских сточных вод, Стройиздат: Москва, 1984, 89.

[4] Котинав, В.Ф.; Котинав, И.В., Озонирование воды, Стройиздат: Москва, 1974, 112.

[5] Сидько, Р.Я.; Кержнер, Б.К.; Гончарук, В.В., Химия и технология воды, 1989, 11(10), 902-905.

[6] Ларина, А.А.; Ставицкая, С.С.; Тарковская, И.А., Катализ и катализаторы, 1992, 28, 48-53.

[7] Ставицкая, С.С.; Гоба, В.Е.; Картель, Н.Т., В кн.: Мікродомішки в воді. Матеріали міжнародного семінару, Київ, 2003, 65.

[8] Ставицкая С.С.; Тарковская, И.А.; Колотуша, Б.И., Украинский химический журнал, 1984, 50(9), 939943.

[9] Лукомская, А.Ю.; Тарковская, И.А., Теоретическая и экспериментальная химия, 1986, 22(6), $25-28$.

[10] Stavitskaya, S.S.; Strelko, V.V.; Kartel, N.T.; Tarkovskaya, I.A., In: Interfaces Against Pollution. Proceedings of the $3^{\text {rd }}$ International Conference, Julich, Germany, 2004, 152.

[11] Тарковская, И.А.; Ставицкая, С.С.; и др., Химическая технология, 1991, 2. 14-19.

[12] Тарковская, И.А.; Шпота, Г.П., Теоретическая и экспериментальная химия, 1986, 22(5), 17-20.

[13] Тарковская \. И.А.; Гоба В.Е.; Томашевская, А.Н.; и др., Химия и технология воды, 1992, 14(5), $348-356$.

[14] Ставицкая, С.С.; Тарковская, И.А.; Гороховатская, Н.В.; и др., Украинский химический журнал, 1990, 56(7), 723-726. 